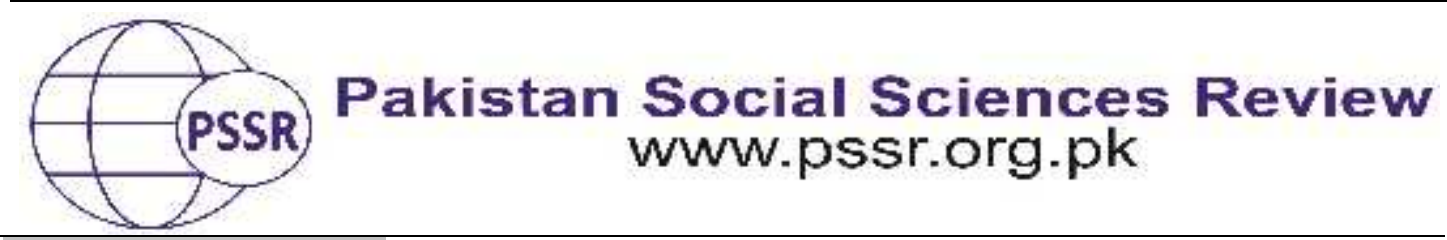

RESEARCH PAPER

\title{
Exchange Rate Volatility with Third-Country Risk Impact: A Bilateral Analysis of Pakistan with Major Trading Partners
}

\author{
Ghosia Ayaz Abbasi ${ }^{1}$ Javed Iqbal ${ }^{2}$
}

1. Ph. D. Scholar, School of Economics, Quaid-i-Azam University Islamabad, Pakistan

2. Associate Professor, School of economics, Quaid-i-Azam University, Islamabad, Pakistan

\begin{tabular}{|c|c|}
\hline I AOEN MIVT & מה \\
\hline $\begin{array}{l}\text { d: } \\
3,2020 \\
\text { d: } \\
05,2020 \\
\\
31,2020\end{array}$ & $\begin{array}{l}\text { A large body of literature has examined the impact of real } \\
\text { exchange rate fluctuation on trade flows. Most of the studies } \\
\text { report both positive and negative impact of exchange rate } \\
\text { fluctuations on trade flows. In recent years, many studies point } \\
\text { to the fact that third-country exchange rate risk also plays a vital }\end{array}$ \\
\hline $\begin{array}{l}\text { rds: } \\
\text { fe Rate } \\
\text { ountry } \\
\text { y }\end{array}$ & $\begin{array}{l}\text { Thus, this study aims to investigate } \\
\text { hange rate movements as well as } \\
\text { risk on trade flows of Pakistan vis- } \\
\text { thers. Hence all the previous studies } \\
\text { sults, thus this research contributes } \\
\text { e rate and third country volatility } \\
\text { rading partners. The study employs }\end{array}$ \\
\hline $\begin{array}{l}\text { Cor } \\
\text { Aut }\end{array}$ & $\begin{array}{l}\text { the Autoregressive Distributed Lag Bounds testing Approach to } \\
\text { co integration. This piece of research work finds significant } \\
\text { evidence of the real exchange rate volatility and the third- } \\
\text { country risk impacts. The results point to the fact that when } \\
\text { evaluating the implications of bilateral exchange rate } \\
\text { uncertainty on bilateral trade flows, the third country exchange } \\
\text { rate risk also needs to be taken into consideration. }\end{array}$ \\
\hline
\end{tabular}

\section{Introduction}

Several studies have emerged since the implementation of the floating exchange rate system during the 1970s, after the collapse of the Bretton-Wood system, to show the relationship between currency fluctuations and international trade (Bordo, 2017). Since then, the conflict has been strengthened by the adoption of a common currency in Europe. A large part of studies refers that trade is necessary for development (Aizenmen \& Lee, 2010; Bahmani-Oskooee \& Arize 2019). Such a finding stems from research that suggests that outward-oriented economies have consistently higher rates of growth than inward-oriented ones.

In the case of Pakistan, all the previous studies reveal that there is conflicting evidence about the relationship between trade and exchange rate volatility. No clear 
pattern of results or consistent conclusions emerges from these studies. In light of the foregoing arguments, the issue of the relationship between exchange-rate volatility and international trade appears to be an empirical question. There is no empirical evidence specifically regarding Pakistan and the studies are considered to be representative of the developing countries. Secondly, most of the recent studies rely on the mere impact of ER-fluctuations that are the result of frequent appreciation as well as depreciation pressures that are supposed to affect international trade.

However, in the case of many major economic variables such as thirdcountry exchange rate and its changes along with exchange rates are persistent and prevailing. Hence, relying on mere exchange rates may mask the relationship among variables and forecasting results. The finding of Baek (2014) confirmed that the response of exports may change the track to changes in the third-country exchange rate. Lastly, the previous empirical work has been able to capture the results that are appeared to be country specific. Hence the purpose of this study is to examine not merely the effects of exchange rate changes especially for Pakistan vis-à-vis her major trading partners but how the presence of third-country exchange rate risk affects this relationship. This may be the better representation of the effects of exchange rate variability along with third country in this region as Pakistan is one of its emerging states and may help other people to go deep into this analysis and make further attempts to find the correct answer which will help in appropriate economic decision making.

\section{Literature review}

Extant studies report that international trade is sensitive enough to increasing uncertainty in exchange rates (Yarmekhamedov, 2007; BAAK, 2008; Bourdon and Korinek, 2011; Eichengreen and Gupta, 2012; Baek, 2013; Kurihara, 2013; Guneren and Kibritci, 2014; Hou, 2014; Leigh et al, 2017).The latest study by Kurihara (2013) showed that volatility exchange has a negative influence on international trade in developing countries. As the exchange rate of uncertainty increases it will hurt international trade. On the other hand, the situation would be reversed if hedging or covering instruments have been created to counter volatility in the exchange rates as financial market growth has been achieved in these countries. Hou (2014) discussed the effects on general trade exports of the real effective exchange rate were greater than the impact on the export processing industry. Another study byGuneren and Kibritci (2014) described a significant co-integrated relationship between effective exchange rates and long-term exports/imports of emerging countries.

Besides, few studies have focused on emerging and newly developed economies Sherzod (2007) discovered that short-term consequences of price shifts are negatively associated with exports and imports in Sweden. The relationship appears to be optimistic when traders are aware of the fluctuations in the previous period made reasonable decisions regarding the amount of their trade. In the same way, B.A.A.K (2008) suggested that China's Renminbi value has long-term adverse impacts on China's exports. Bourdon and Korinek (2011) having a different view, 
noted that exchange rates do not affect trade flows in large economies, while they do in smaller economies or developing countries. Baek (2013) showed Korea's exports and imports are fairly sensitive to the bilateral exchange ratein the short-run, but in the long run less responsive. Leigh et al (2017) evaluated that exchange-rate depreciation will mostly impact economies with economic slackness.

On the other hand, many studies (Marquez and Schindler, 2006; Jiang, 2014; Baek, 2014; Serenis and Serenis 2010; Serenis and Tsounis, 2014) presented an optimistic view that there is a positive relationship exists between exchange rate fluctuation and international trade. Marquez and Schindler (2006) indicated that real RMB appreciation of 10 percent would lower the share of aggregate Chinese exports by half a percentage point. Additionally, Jiang (2014) revealed that the nominal fluctuation in the RMB exchange rate is the main factor affecting China's imports and exports. In the long run, the rise in the RMB exchange rate, which means the devaluation of RMB, will have a positive effect on foreign trade, as well as a significant increase in domestic import and export volumes. Baek (2014) found that Korea's major export industries account for nearly 75 percent of total exports are highly responsive to the long- and short-run bilateral exchange rate, uncertainty, and the impact of third countries

The third view in this regard is different. Tenreyro (2007); Nicita (2013); Simakova (2014) and Su et al. (2017) demonstrated that international trade tends to be influenced by factors other than exchange-rate developments. Nicita (2013) found that exchange rate volatility would not impact international trade except currency unions and fixed exchange rates occur but give more weight to other factors. Thus there is no consensus over the relationship between the volatility of the exchange rate and international trade. Rather the nature of the relationship finds a different direction and floats a different kind of discussion than just to be symmetric (Bahmani et al. 2016; Arize et al., 2017; Bahmani and Aftab 2017; Bahmani and Gelen, 2018; Bahmani and Arize 2019).

Pakistan since its inception is facing the problem of an unfavorable balance of payments and declining exports due to its undeveloped infant industry problems. Hence to boost its infant industry and exports Pakistan devalued its currency in the year 1952 for the first time. This resulted in a buildup of inflationary pressure from time to time within the country. Later, when Pakistan delinked its currency from the US dollar in 1973, it had to face the major problem of continued depreciation except for a few years in the decade of 1990 (Khattak et al. 2012). The previous studies on the impact of ER-Volatility on international trade flows of Pakistan are quite ambiguous.Empirical literature regarding the impact of exchange rate uncertainty in Pakistan includes the studies by Kumar and Dhawan (1991); Kemal (2005); Shahbaz et al. (2010); Razi et al. (2012);Aftab et al. (2012). More recent literature adds studies by Khan et al. (2014); Hussain et al. (2015); Latief and Lefen (2018). All the studies while conducting different aspects of the research, presented the negative effect of ER-volatility on international trade. Besides, the results of all these previous studies 
are appeared to be country specific but all these studies have been unable to analyze the impact of third-country exchange rate risk even at the aggregate level trade.

\section{Model and Methods}

Export flows are generally modeled as any other demand model, i.e. exports are inversely related to relative prices and positively affected by the foreign income. Hence, the standard specifications cited in many of the recent research studies (e.g, Bahmani-Oskooee and Harvey, 2011; Arize and Mailindretos, 2016; Bahmani-Oskooe and Aftab, 2017; Arize et al., 2017) are as follows to capture bilateral volatility effects:

$$
\ln \left(X_{\mathrm{t}}\right)=\beta_{0}+\beta_{1} \ln \left(Y_{\mathrm{E}, \mathrm{t}}\right)+\beta_{2} \ln \left(\mathrm{RER}_{\mathrm{t}}\right)+\beta_{3} V_{\mathrm{t}}+\mu_{\mathrm{t}}
$$

This can be extended following Kumar and Dhawan (1991) to equation 2 to compute third country risk effect on exports:

$$
\ln \left(X_{\mathrm{t}}\right)=\beta_{0}+\beta_{1} \ln \left(Y_{\mathrm{E}, \mathrm{t}}\right)+\beta_{2} \ln \left(\mathrm{RER}_{\mathrm{t}}\right)+\beta_{3} V_{\mathrm{t}}+\beta_{4} T C V_{\mathrm{t}}+\mu_{\mathrm{t}}
$$

Where $X$ is the real exports of Pakistan and $t$ represent time and $\beta i$ (where $i=$ $0,1,2,3,4)$ captures model parameters. $Y_{F}$ represents the real foreign income of each respective trading partner and RER denotes the real bilateral exchange rate between Pakistan and respective trading partner, $\mathrm{V}$ is the real bilateral exchange rate volatility and TCV captures third-country exchange rate variability impact in which exchange rate between Pak-rupee and US-dollar is taken means US-dollar is used as vehicle currency to capture this volatility, $\mu$ is the stochastic error term According to theory, as foreign income increases there will be a positive impact on exports so $\beta 1$ is expected to be positive, $\beta 2$ is negative as the exchange rate is taken as the numbers of units of domestic currency per unit of foreign currency so the real depreciation of exchange rate causes to increase exports and $\beta 3$ and $\beta 4$ are expected to have ambiguous impacts.

The study uses Autoregressive Distributed Lag (ARDL) bounds test approach proposed by Pesaran et al. (2001) and the moving standard deviation measure of exchange rate volatility to estimate the export demand models in equations (1) and (2). The models capable of dealing with both stationary $i(0)$ and nonstationary I (1) variables and provides short as well as long-term results.

Equations 1 and 2 are the long-term relations among the variables in our models. To implement the ARDL approach to cointegration into this model, first, the short-term dynamics need to be added into the long-term. The short-run equations corresponding to the long-run equations 1 and 2 can be written as follows: 


$$
\begin{aligned}
& \Delta x_{t} \\
& =\beta_{0}+\beta_{1} \sum_{j=1}^{n 1} \Delta x_{t-j}+\beta_{2} \sum_{j=0}^{n z} \Delta y_{F, t-j}+\beta_{3} \sum_{j=0}^{n 3} \Delta r e r_{t-j}+\beta_{4} \sum_{j=0}^{n 4} \Delta V_{t-j} \\
& +\left(\gamma_{1} x_{t-1}+\gamma_{2} y_{F, t-1}+\gamma_{3} r e r_{t-1}+\gamma_{4} V_{t-1}\right) \\
& +v_{t}
\end{aligned}
$$

We will estimate both the linear ARDL models in 3 and 4 in the next section.

\section{The Data}

We select the annual data from 1982 to 2017. The study includes a sample of countries i.e. Pakistan, European Union (EU), United States of America (USA), CHINA, Saudi Arabia (KSA), and United Arab Emirates (UAE). The data for exports are taken from COMTRADE and the data for nominal exchange rates, consumer price index (CPI), and real GDP come from the International Financial Statistics of the IMF for USA, CHINA, UAE and KSA and for EU data are taken from EUROSTAT.

\section{The Variables}

\section{Real Exports $\left(X_{i}\right)$}

The real exports variable is defined as the ratio of Pakistan's exports to country i over its export price to country i. Real exports variable is obtained by dividing the exports to trading partner " $\mathrm{i}$ " with the price of exports or $\mathrm{Xi} / \mathrm{PXi}$." $\mathrm{Xi}=$ Volume of exports of commodity "I" by Pakistan to each trading partner. The main advantage of taking real exports is that they are unit free. Secondly, it would help to calculate exactly the trade surplus/deficit of Pakistan for each country.

\section{Real GDP}

In the analysis, we use the real GDP of each of Pakistan's trading partners. We use the index of real GDP as a proxy for both countries. It is assumed that the real GDP of Pakistan's trading partner is positively related to the real exports of Pakistan. This is because if the income of the people abroad or trading partner 
country of Pakistan will increase, they will increase the demand for imports, and Pakistan's exports will increase thus resulting in improving the trade deficit problem.

\section{Real Bilateral Exchange Rate (RER)}

The variable for RER is constructed by dividing each country's nominal exchange rate by its consumer price index (CPI). In our particular case, RER is defined as the number of units of domestic currency per unit of foreign currency. Therefore, an increase in the value of RER means that the Pakistani rupee has depreciated concerning the currency of foreign trading partners. We expect the coefficient of RER to be negative if depreciation and devaluation are going to have a favorable effect on exports/trade.

\section{Volatility of Real Exchange Rate (V)}

"“VPakI= Volatility measure of the real bilateral exchange rate between the rupee and each of the trading partner's currency $(I=1 \ldots . .5)$. We first construct the real rate as RERPakI $=\left(\mathrm{PI}^{*} \mathrm{NERPakI}\right) / \mathrm{PPak}$, where NERPakI is the nominal exchange rate defined as number of rupees per I; PI is each trading partner's CPI respectively and PPak is the Pakistani CPI. Then, again, for each year we define this volatility measure as the standard deviation of 12 monthly RERPakI within that year. Monthly CPI data and nominal exchange rate data for each trading partner come from " $\mathrm{b}$ " and for EU come from source " $c$ "."

\section{Results and Discussion}

We estimate both the linear ARDL models in 3 and 4 in the case of Pakistan with its major five trading partners: EU, USA, China, Saudi Arabia, and UAE to see whether there are the effects of changes in the exchange rate along with thirdcountry exchange rate. The study uses yearly data from 1982 to 2017. Following the Pesaran et al. (2001), the study uses the Akaike's Information Criterion (AIC) to choose the optimal lag length. We follow the automatic lag selection and allow a maximum of three or four lags due to the data being used annually. Table 1 to 10 in the Appendix provides the estimation results of our bound testing approach to cointegration. In each table, there are three panels. Panel A gives the short-run coefficients, Panel B gives the long-run coefficients, and Panel C provides the diagnostic statistics of the estimation process.

We first consider bilateral trade between Pakistan and the US; the estimates for both models i.e. (3) and (5) are reported in Table 1. The estimates of the linear ARDL model show that two variables i.e. RER and V out of the three are significant in the short run but in the case of the long run, only the exchange rate has a significant effect on the exports. The exchange rate has a favorable effect on trade both in the short run and in the long run for the Pakistan-US case. The negative 
coefficient of exchange rate implies that when the value of RER increases (depreciation of the rupee), real exports will decrease.

Table 1

ER-Volatility Results for US

\begin{tabular}{|c|c|c|c|c|c|c|c|}
\hline \multicolumn{8}{|c|}{ Linear ARDL model estimates } \\
\hline Lags & 0 & 1 & 2 & 3 & 4 & 5 & 6 \\
\hline \multicolumn{8}{|c|}{ Panel A: Short run results } \\
\hline$\Delta \ln X$ & & $-0.26(1.95)$ & & & & & \\
\hline$\Delta \operatorname{lnYUS}$ & $0.19(0.57)$ & & & & & & \\
\hline$\triangle \ln R E R$ & $-0.44(1.17)$ & $-0.29(2.89)$ & $-0.96(2.28)$ & & & & \\
\hline$\Delta \ln V$ & $0.25(0.17)$ & $-3.33(2.88)$ & $-0.72(0.62)$ & & & & \\
\hline \multicolumn{8}{|c|}{ Panel B: Long run results } \\
\hline \multirow[t]{2}{*}{ Variables } & Constant & $\operatorname{lnRYUS}$ & $\operatorname{lnRER}$ & $\ln \mathrm{V}$ & & & \\
\hline & $-17.61(0.65)$ & $0.76(0.78)$ & $2.06(2.82)$ & $15.94(1.42)$ & & & \\
\hline \multicolumn{8}{|c|}{ Panel C: Diagnostic results } \\
\hline & $\mathrm{F}$ & Adj R2 & LM & ECMt-l & RESET & $\mathrm{CU}$ & CU2 \\
\hline & 7.91 & 0.52 & 1.22 & $-0.26(6.86)$ & 3.36 & $S$ & $S$ \\
\hline \multicolumn{8}{|c|}{ Note: Numbers in brackets are the absolute t-statistics } \\
\hline
\end{tabular}

Panel C of Table 1 shows that the F-stat calculated is greater than its upper bound critical value of 7.91 (5\% significance level), therefore it confirms cointegration. The negative significant value of the error correction term $\left(\mathrm{ECM}_{\mathrm{t}-1}\right)$, on the other hand, also confirms the existence of cointegration. The coefficient of $\mathrm{ECM}_{\mathrm{t}-1}$ shows the speed of adjustment to the equilibrium level. The $\mathrm{t}$-values for $\mathrm{ECM}_{\mathrm{t}-1}$ are given by Banerjee et. al., (1998, Table 1). The critical t-value in our case is 3.82 (5\% significance level). Other diagnostic statistics are also given in Panel C. For the results to be valid, the coefficient should be stable, the serial correlation should be absent, and the functional form of the model should correctly be specified.

The Regression Specification Error test (RESET), which is proposed by Ramsey (1969), the Lagrange Multiplier (LM), and CUSUM (CU) and CUSUM of Square $\left(\mathrm{CU}^{2}\right)$ tests reported at bottom of Panel C confirm that the model is correctly specified [e.g., Pesaran et al. (2001), and Bahmani-Oskooee et al. (2005)], as well as there is no autocorrelation, and the coefficients are stable. The graphical representation of each test here will make the process lengthy therefore we present the symbol of $S$ for stable coefficients and the US for unstable coefficients at a $5 \%$ significance level. The estimated results suggest that the volatility effect is not supported by the linear ARDL approach in the case of Pak-US bilateral trade.

Next, we consider the estimates of third-country exchange raterisk impact. The third country volatility (TCV) effect results are reported in Table 2 which indicates that uncertainty of third-country exchange rate has no short-runbut long-run effects in the linear model. This supports the effects of third-country volatility to be stronger than the mere effects of bilateral volatility. 
Table 2

Empirical Results of TCV for US

\begin{tabular}{|c|c|c|c|c|c|c|c|}
\hline \multicolumn{8}{|c|}{ Linear ARDL model estimates } \\
\hline Lags & 0 & 1 & 2 & 3 & 4 & 5 & 6 \\
\hline \multicolumn{8}{|c|}{ Panel A: Short run results } \\
\hline$\Delta \ln X$ & & $-0.40(1.31)$ & $-0.43(-1.39)$ & $-0.52(-2.04)$ & & & \\
\hline$\Delta \ln Y U S$ & $-1.75(1.61)$ & & & & & & \\
\hline$\Delta \operatorname{lnRER}$ & $0.09(0.18)$ & $0.83(1.07)$ & $-0.74(1.20)$ & $0.91(1.42)$ & & & \\
\hline$\Delta \ln \mathrm{V}$ & $-4.27(1.69)$ & $-1.37(0.39)$ & $-1.17(0.51)$ & $-1.65(1.35)$ & & & \\
\hline$\Delta \operatorname{lnTCV}$ & $-0.10(0.42)$ & $0.52(1.22)$ & $0.20(0.71)$ & $0.19(1.18)$ & & & \\
\hline \multicolumn{8}{|c|}{ Panel B: Long run results } \\
\hline & Constant & $\ln \mathrm{YUS}$ & $\ln$ RER & $\ln \mathrm{V}$ & $\operatorname{lnTCV}$ & & \\
\hline & $-14.97(1.47)$ & $5.28(1.56)$ & $0.29(0.34)$ & $15.45(1.63)$ & $0.79(0.27)$ & & \\
\hline \multicolumn{8}{|c|}{ Panel C: Diagnostic results } \\
\hline & $\mathrm{F}$ & Adj R2 & LM & ECMt-1 & RESET & $\mathrm{CU}$ & CU2 \\
\hline & 3.01 & 0.71 & 5.27 & $0.33(5.20)$ & 0.48 & $S$ & S \\
\hline
\end{tabular}

Note: Numbers in brackets are the absolute t-statistics

As far as, the bilateral trade between Pakistan and EU is concerned, the results of exchange rate volatility effects reported in Table 3 postulate that all the three variables of $\mathrm{Y}_{\mathrm{EU}}, \mathrm{RER}$, and $\mathrm{V}$ are significant in the short run with expected signs but only the volatility of the real exchange rate and EU's real income display significant long-run inverse effects and real exchange rate discloses though negative but insignificant impact in the long run.

Table 3

ER-Volatility Results for EU

\begin{tabular}{|c|c|c|c|c|c|c|c|}
\hline \multicolumn{8}{|c|}{ Linear ARDL model estimates } \\
\hline Lags & 0 & 1 & 2 & 3 & 4 & 5 & 6 \\
\hline \multicolumn{8}{|c|}{ Panel A: Short run results } \\
\hline$\Delta \ln X$ & & $0.01(0.13)$ & $-0.26(2.72)$ & & & & \\
\hline$\triangle \operatorname{lnYEU}$ & $-1.88(2.70)$ & $2.87(3.67)$ & $-2.37(3.20)$ & & & & \\
\hline$\triangle \ln R E R$ & $-0.31(3.55)$ & & & & & & \\
\hline$\Delta \ln V$ & $-1.92(3.66)$ & & & & & & \\
\hline \multicolumn{8}{|c|}{ Panel B: Long run results } \\
\hline \multirow[t]{2}{*}{ Variables } & Constant & $\operatorname{lnYEU}$ & ln RER & $\ln \mathrm{V}$ & & & \\
\hline & $-67.18(2.74)$ & $2.80(3.36)$ & $-0.29(1.27)$ & $-7.00(2.76)$ & & & \\
\hline \multicolumn{8}{|c|}{ Panel C: Diagnostic results } \\
\hline & $\mathrm{F}$ & Adj R2 & LM & ECMt-1 & RESET & $\mathrm{CU}$ & CU2 \\
\hline & 12.10 & 0.76 & 1.63 & $-0.27(8.49)$ & 0.46 & $S$ & S \\
\hline \multicolumn{8}{|c|}{ Note: Numbers in brackets are the absolutet-statistics } \\
\hline
\end{tabular}


The estimates of third country real exchange rate volatility in Table 4 for EU show the significant third-country exchange rate instability effects in the short run. Results for the EU which are reported in Table 4 for short run are quite different than those for the US. The variability in the third country exchange rate has stronger effects for short run but it shows no significant influence for long run.

Table 4

Empirical Results of TCV for EU

\begin{tabular}{|c|c|c|c|c|c|c|c|}
\hline \multicolumn{8}{|c|}{ Linear ARDL model estimates } \\
\hline Lags & 0 & 1 & 2 & 3 & 4 & 5 & 6 \\
\hline \multicolumn{8}{|c|}{ Panel A: Short run results } \\
\hline$\Delta \ln X$ & & $-0.32(2.74)$ & $-0.31(2.88)$ & & & & \\
\hline$\triangle \ln Y E U$ & $-1.67(2.28)$ & $4.81(6.52)$ & & & & & \\
\hline$\triangle \ln R E R$ & $-0.27(3.19)$ & $-0.23(2.33)$ & & & & & \\
\hline$\Delta \ln V$ & $-1.45(2.55)$ & $-5.96(7.51)$ & $-3.32(4.65)$ & $-1.51(3.34)$ & & & \\
\hline$\Delta \operatorname{lnTCV}$ & $-0.15(0.14)$ & $10.24(5.68)$ & $6.52(4.16)$ & $2.55(2.59)$ & & & \\
\hline \multicolumn{8}{|c|}{ Panel B: Long run results } \\
\hline & Constant & $\ln \mathrm{YEU}$ & ln RER & $\ln \mathrm{V}$ & $\operatorname{lnTCV}$ & & \\
\hline & $-50.93(0.21)$ & $17.98(0.22)$ & $-5.08(0.19)$ & $-14.31(0.20)$ & $26.40(0.18)$ & & \\
\hline \multicolumn{8}{|c|}{ Panel C: Diagnostic results } \\
\hline & $\mathrm{F}$ & Adj R2 & LM & ECMt-1 & RESET & $\mathrm{CU}$ & CU2 \\
\hline & 2.22 & 0.84 & 2.32 & $0.03(4.40)$ & 0.24 & $S$ & $S$ \\
\hline
\end{tabular}

As far as, China is concerned, the real exchange rate volatility estimates (Table 5) show that real bilateral exchange rate volatility exerts a significant inverse effect on the Pak-China exports only in the short-run but it displays insignificant effect in the long run though positive.

Table 5

RER-Volatility Results for China

\begin{tabular}{|c|c|c|c|c|c|c|c|}
\hline \multicolumn{8}{|c|}{ Linear ARDL model estimates } \\
\hline Lags & 0 & 1 & 2 & 3 & 4 & 5 & 6 \\
\hline \multicolumn{8}{|c|}{ Panel A: Short run results } \\
\hline$\triangle \ln Y C H$ & $11.34(4.52)$ & $-12.11(3.71)$ & $8.93(3.96)$ & & & & \\
\hline$\Delta \operatorname{lnRER}$ & $0.70(1.26)$ & & & & & & \\
\hline$\Delta \ln \mathrm{V}$ & $-2.45((0.99)$ & $4.09(1.83)$ & $-6.89(3.27)$ & & & & \\
\hline \multicolumn{8}{|c|}{ Panel B: Long run results } \\
\hline \multirow{2}{*}{ Variables } & Constant & $\ln \mathrm{YCH}$ & $\ln$ RER & $\ln \mathrm{V}$ & & & \\
\hline & $-2.88(1.17)$ & $1.58(6.05)$ & $1.07(1.27)$ & $1.24(0.09)$ & & & \\
\hline \multicolumn{8}{|c|}{ Panel C: Diagnostic results } \\
\hline & $\mathrm{F}$ & Adj R2 & LM & ECMt-1 & RESET & $\mathrm{CU}$ & CU2 \\
\hline & 5.12 & 0.77 & 3.52 & $-0.66(5.57)$ & 0.84 & $S$ & $\mathrm{~S}$ \\
\hline
\end{tabular}


TCV (Table 6) significantly affect the Pak-China trade only in the short-run and further third country real exchange rate volatility estimates confirm that the real exchange rate volatility displays stronger impact with third country instability impact which can be observed from Table 6 .

Table 6

Empirical Results of TCV for China

\begin{tabular}{|c|c|c|c|c|c|c|c|}
\hline \multicolumn{8}{|c|}{ Linear ARDL model estimates } \\
\hline Lags & 0 & 1 & 2 & 3 & 4 & 5 & 6 \\
\hline \multicolumn{8}{|c|}{ Panel A: Short run results } \\
\hline$\Delta \ln X$ & & $0.27(2.21)$ & $0.25(2.06)$ & $-0.14(1.59)$ & & & \\
\hline$\triangle \ln Y C H$ & $5.22(1.80)$ & $-1.72(0.34)$ & $2.13(0.55)$ & $13.34(3.81)$ & & & \\
\hline$\triangle \ln R E R$ & $-1.47(2.52)$ & $-3.26(4.08)$ & $-0.92(2.11)$ & & & & \\
\hline$\Delta \ln \mathrm{V}$ & $5.40(1.61)$ & $12.40(3.20)$ & $-9.68(3.29)$ & $-14.11(4.72)$ & & & \\
\hline$\triangle \operatorname{lnTCV}$ & $-3.68(1.12)$ & $-7.87(1.98)$ & $10.47(2.53)$ & $17.57(5.44)$ & & & \\
\hline \multicolumn{8}{|c|}{ Panel B: Long run results } \\
\hline & Constant & $\ln \mathrm{YCH}$ & ln RER & $\ln \mathrm{V}$ & $\operatorname{lnTCV}$ & & \\
\hline & $-3.52(0.92)$ & $1.38(3.98)$ & $1.58(1.38)$ & $-7.28(0.36)$ & $6.15(0.59)$ & & \\
\hline \multicolumn{8}{|c|}{ Panel C: Diagnostic results } \\
\hline & $\mathrm{F}$ & Adj R2 & LM & ECMt-1 & RESET & $\mathrm{CU}$ & CU2 \\
\hline & 3.86 & 0.89 & 14.01 & $-0.78(6.30)$ & 0.03 & $S$ & $S$ \\
\hline
\end{tabular}

Estimates for UAE reported in Table 7 are quite different than in the cases of the US and China, results of exchange rate volatility in case of UAE show that bilateral volatility has positive but no significant short-run as well as long-run influence on real exports of Pakistan in our model which are quite different from TCV estimates presented in Table 8.

Table 7

RER-Volatility Results for UAE

\begin{tabular}{|c|c|c|c|c|c|c|c|}
\hline \multicolumn{8}{|c|}{ Linear ARDL model estimates } \\
\hline Lags & 0 & 1 & 2 & 3 & 4 & 5 & 6 \\
\hline \multicolumn{8}{|c|}{ Panel A: Short run results } \\
\hline$\Delta \ln X$ & & $-1.00(5.07)$ & & & & & \\
\hline$\Delta \operatorname{lnYUAE}$ & $1.75(3.49)$ & & & & & & \\
\hline$\Delta \operatorname{lnRER}$ & $-0.42(0.32)$ & & & & & & \\
\hline$\Delta \ln V$ & $10.58(0.98)$ & & & & & & \\
\hline \multicolumn{8}{|c|}{ Panel B: Long run results } \\
\hline \multirow[t]{2}{*}{ Variables } & Constant & $\ln$ YUAE & ln RER & $\ln \mathrm{V}$ & & & \\
\hline & $-31.31(2.45)$ & $1.76(4.87)$ & $-0.41(0.29)$ & $2.58(0.88)$ & & & \\
\hline \multicolumn{8}{|c|}{ Panel C: Diagnostic results } \\
\hline & $\mathrm{F}$ & Adj R2 & LM & ECMt-1 & RESET & $\mathrm{CU}$ & CU2 \\
\hline & 5.36 & 0.47 & 0.05 & $-1.00(5.52)$ & 1.40 & $S$ & $S$ \\
\hline
\end{tabular}


While the estimates of third country instability show the positive impact of TCV in both the short run and the long run. TCV has only significant long-run effects but it appears to be insignificant in the short run. (Table 8).

\section{Table 8}

Empirical Results of TCV for UAE

\begin{tabular}{|c|c|c|c|c|c|c|c|}
\hline \multicolumn{8}{|c|}{ Linear ARDL model estimates } \\
\hline Lags & 0 & 1 & 2 & 3 & 4 & 5 & 6 \\
\hline \multicolumn{8}{|c|}{ Panel A: Short run results } \\
\hline \multicolumn{8}{|l|}{$\Delta \ln X$} \\
\hline$\Delta \ln Y \mathrm{UAE}$ & $-3.62(1.87)$ & & & & & & \\
\hline$\triangle \operatorname{lnRER}$ & $-2.58(1.16)$ & $-3.23(1.53)$ & $-9.46(4.45)$ & & & & \\
\hline$\Delta \ln V$ & $-27.89(1.77)$ & $-21.97(1.11)$ & $\begin{array}{l}- \\
34.25(2.18)\end{array}$ & & & & \\
\hline$\triangle \operatorname{lnTCV}$ & $32.23(2.29)$ & $47.53(2.70)$ & $68.95(3.81)$ & $23.04(3.02)$ & & & \\
\hline \multicolumn{8}{|c|}{ Panel B: Long run results } \\
\hline & Constant & $\ln \mathrm{YUAE}$ & ln RER & $\ln \mathrm{V}$ & $\operatorname{lnTCV}$ & & \\
\hline & $-55.37(2.92)$ & $2.19(4.48)$ & $3.72(1.56)$ & $\begin{array}{l}- \\
29.31(0.50)\end{array}$ & $20.94(0.48)$ & & \\
\hline \multicolumn{8}{|c|}{ Panel C: Diagnostic results } \\
\hline & $\mathrm{F}$ & Adj R2 & LM & ECMt-1 & RESET & $\mathrm{CU}$ & CU2 \\
\hline & 5.39 & 0.61 & 1.34 & $1.07((6.62)$ & 0.00 & $S$ & $S$ \\
\hline
\end{tabular}

The estimated results for KSA are reported in Tables 9 and 10 of RERvolatility and TCV respectively, which indicate that exchange rate variability has significantly hurt the exports in the short run.

Table 9

ER-Volatility Results for KSA

\begin{tabular}{|c|c|c|c|c|c|c|c|}
\hline \multicolumn{8}{|c|}{ Linear ARDL model estimates } \\
\hline Lags & 0 & 1 & 2 & 3 & 4 & 5 & 6 \\
\hline \multicolumn{8}{|c|}{ Panel A: Short run results } \\
\hline$\Delta \ln X$ & & $-0.67(2.33)$ & & & & & \\
\hline$\Delta \ln Y K S A$ & $0.23(3.65)$ & $1.34(2.56)$ & & & & & \\
\hline$\Delta \operatorname{lnRER}$ & $-0.54(3.17)$ & $-1.29(2.64)$ & $-0.76(2.28)$ & & & & \\
\hline$\Delta \ln V$ & $-1.05(2.17)$ & $-2.13(2.65)$ & $-1.52(2.62)$ & & & & \\
\hline \multicolumn{8}{|c|}{ Panel B: Long run results } \\
\hline \multirow[t]{2}{*}{ Variables } & Constant & $\ln \mathrm{YKSA}$ & ln RER & $\ln \mathrm{V}$ & & & \\
\hline & $-7.01(0.54)$ & $2.16(3.44)$ & $-2.36(2.53)$ & $5.04(0.89)$ & & & \\
\hline \multicolumn{8}{|c|}{ Panel C: Diagnostic results } \\
\hline & $\mathrm{F}$ & Adj R2 & LM & ECMt-1 & RESET & $\mathrm{CU}$ & CU2 \\
\hline & 5.91 & 0.42 & 1.32 & $-0.46(5.55)$ & 0.36 & $S$ & $S$ \\
\hline
\end{tabular}

Note: Numbers inside the brackets beside coefficients are the absolute values of $t$-ratios

However, the estimates of the effects of TCV are reported in Table 10. The estimates suggest that instability of the exchange rate has significant short-run as 
well as long-run effects on the real exports of Pakistan. Also, positive TCV effects are found in long run in our model.

Table 10

Empirical Results of TCV for KSA

\begin{tabular}{|c|c|c|c|c|c|c|c|}
\hline \multicolumn{8}{|c|}{ Linear ARDL model estimates } \\
\hline Lags & 0 & 1 & 2 & 3 & 4 & 5 & 6 \\
\hline \multicolumn{8}{|c|}{ Panel A: Short run results } \\
\hline$\Delta \ln X$ & & $-0.40(1.97)$ & $0.43(2.11)$ & $-0.34(2.65)$ & & & \\
\hline$\Delta \ln Y K S A$ & $0.22(2.89)$ & & & & & & \\
\hline$\Delta \operatorname{lnRER}$ & $-0.09(2.01)$ & $0.83(2.23)$ & $-0.73(2.85)$ & & & & \\
\hline$\Delta \ln \mathrm{V}$ & $-4.27(2.34)$ & $-1.37(1.89)$ & $-1.17(1.45)$ & $-1.65(1.23)$ & & & \\
\hline$\Delta \operatorname{lnTCV}$ & $-0.13(0.88)$ & $0.52(1.21)$ & $0.74(1.89)$ & $-0.19(2.11)$ & & & \\
\hline \multicolumn{8}{|c|}{ Panel B: Long run results } \\
\hline & Constant & $\ln \mathrm{YKSA}$ & ln RER & $\ln \mathrm{V}$ & $\operatorname{lnTCV}$ & & \\
\hline & $-4.97(0.33)$ & $5.27(3.21)$ & $-0.39(0.93)$ & $-6.45(2.23)$ & $1.79(2.11)$ & & \\
\hline \multicolumn{8}{|c|}{ Panel C: Diagnostic results } \\
\hline & F & Adj R2 & LM & ECMt-1 & RESET & $\mathrm{CU}$ & CU2 \\
\hline & 4.01 & 0.81 & 0.27 & $-0.23(4.20)$ & 1.38 & $S$ & $S$ \\
\hline
\end{tabular}

Following Arize et al. (2017) Bahmani and Aftab (2017) and Bahmani and Arize (2019), the results are not consistent in the case of the linear ARDL approach while considering bilateral volatility alone. The results get reversed in the case of third-country risk impact. In all the cases the adverse short-run effect of exchange rate uncertainty on the exports is found but the long-run effect is greatly significant with third-country instability thus confirming the presence of the third country volatility effect. In all the cases positive third country volatility effect is found in either the short or long run while diagnostic statistics also show that the results are sensible.

Now considering the impact of the income of Pakistan's trading partners on the real exports, it should be positive. The long-run significant results for Pakistan's trading partners' income on the real exports are found in all the cases of EU, China, UAE, and KSA, and the USA. The implication is that as the income of these countries increases that makes them import more, thus positively affecting real exports of Pakistan and help them to boost.

Whereas we assume that the appreciation (increase) in Pakistan's RER will influence its real exports adversely. This is because as the RER of Pakistan increases, it will increase its demand for imports. After all, imports get cheaper and exports get expensive, so other countries will import less from Pakistan and its exports will decrease. The estimates of RER, in the long run, are only significant in the case of Pakistan-USA, Pakistan-EU, and Pakistan-KSA. In the Pakistan-USA case, significant RER estimates are obtained in the ARDL model for Volatility effects. In the case of Pak-EU, the estimates of RER obtained for both volatility and TCV effect results are insignificant. The same is the case with UAE real bilateral exchange rate affects 
Pakistan's real exports insignificantly in both empirical results for volatility and TCV effects.

\section{Summary and Conclusion}

For the past three decades, the role of the exchange rate in determining trade flows has been a major part of international trade studies. The importance of the exchange rate in improving the overall balance of payments and the effects of its volatility has been discussed at great length. There are both proponents and opponents of the significant effect of the exchange rate volatility on international trade. The research is moving forward with new and enhanced regression models in this area. Researches Initiated with various time series and panel data techniques. The Ordinary Least Square technique is used in the beginning then research was moved towards using Gravity models. Initially, researchers were of the view that it was volatility that had a major impact on trade flows but now, third-country volatility effects became the focus of the research due to globalization and growing interaction in-between countries. The results of the aggregate level, bilateral level, and industry level studies are indecisive about the existence of the effect of the volatility of the exchange rate. In this study, we tried to study the effect of thirdcountry ER-volatility along with ER-uncertainty in Pakistan. The study first checked the exchange rate volatility affect exports then includes the third-country risk impact to see the changes. The findings of the study suggest that exchange rates instability does not have strong effects on the real exports but a consistent effect of TCV was observed in each of the trading partner's cases. This situation obtained when the ARDL approach to cointegration was applied and evidence of the TCV effect was found in the case of all countries i.e., UAE, EU, China, and KSA except the USA. The lack of evidence for volatility effects (TCV) in the case of the USA may be due to the limited nature of data that we have used, or the annual data were taken. Also, the limited number of lags may be the source of limited results. Future research should take a large dataset of quarterly nature. In doing so the results may turn out to be supportive in finding out volatility effects. We could test with other major trading partners of Pakistan so that the results are more generalizable and quotable.

In terms of policy implications, the results show that Pakistan cannot simply improve its trade by depreciating its currency rather it has to ponder over other factors like third country ER-volatility effects along with just ER-variability effects. This is because the effect of the exchange rate instability is not significant for most countries but we have got strong third-country effects. It will be in the best interest of Pakistani policymakers to focus on other policies to increase their trade with the world instead of manipulating the currency on regular basis. The focus should be made on value addition in the production process so that exports could increase, and domestic consumers could buy domestically produced goods. Import-substituting policies in the production of capital goods and other luxury items should be focused on. More emphasis should be given to enhancing the quality of domestically produced goods so that our industries could compete at the international level and 
Exchange Rate Volatility with Third-Country Risk Impact:

A Bilateral Analysis of Pakistan with Major Trading Partners

go a long way in improving our trade worldwide which will, in turn, improve the well-being of common people. 


\section{References}

Aftab, M., Abbas, Z. \&Kayani, F. N. (2012). Impact of exchange rate volatility on sectoral exports of Pakistan: an ARDL investigation. Journal of Chinese Economic and Foreign Trade Studies Volume 5, Issue. 3, ISSN 1754-4408

Aizenman, J. \& Lee, J. (2010).Real Exchange Rate, Mercantilism, and the Learning by Doing Externality Pacific 724 Economic Review, 15(3), 324-335

Arize, A. C., Malindretos, J. \&Igwe, E. U. (2017). Do exchange rate changes improve the trade balance: An asymmetric nonlinear cointegration approach. International Review of Economics $\mathcal{E}$ Finance, Elsevier, vol. 49(C), pages 313-326. https://ideas.repec.org/s/eee/reveco.html.

SaangJoon, B. A. A. K. (2008). The bilateral real exchange rates and trade between China and the US China Economic Review, 19(2), 117-127

Baek, J. (2013). Does the exchange rate matter to bilateral trade between Korea and Japan? Evidence from commodity trade data Economic Modeling, 30, 856-862.

Baek, J. (2014). Exchange rate effects on Korea-US bilateral trade: A new look Research in Economics, 68(3), 214-221

Bahmani-Oskooee, M. \&Aftab, M. (2017). On the asymmetric effects of exchange rate volatility on trade flows: New evidence from US-Malaysia trade at the industry level Economic Modeling, 63, 86-103.

Bahmani-Oskooee, M. \& Harvey, H. (2011). Exchange-rate volatility and industry trade between the US and Malaysia Research in International Business and Finance, 25(2), 127-155

Bahmani-Oskooee, M. \&Arize, A. C. (2019). On the Asymmetric Effects of Exchange Rate Volatility on Trade Flows: Evidence from Africa. Emerging Markets Finance and Trade; $1-27$

Bahmani-Oskooee, M., Halicioglu, F. \&Ghodsi, S. (2016). Asymmetric effects of exchange rate changes on British bilateral trade balances 18th Annual Conference of ETSG, Helsinki-Finland.

Bahmani-Oskooee, M. \&Gelan, A. (2018). Exchange-rate volatility and international trade performance: Evidence from 12 African countries Economic Analysis and Policy, 58, 14-21.

Bordo, Michael D. (2017). The Operation and Demise of the Bretton Woods System; 1958 to 1971 Rutgers University, NBER, and Hoover Institution, Stanford University Economics Working Paper 16116 
Bourdon, H. M. \&Korinek, J. (2011). To what extent do exchange rates and their volatility affect trade? OECD Trade Policy papers, NB No. 1-139

Choudhry, T. \& Hassan, S.S.U. (2013). UK Imports from Germany, Japan and the US: Evidence from Asymmetric Nonlinear ARDL International Review of Financial Analysis.Fourth World Finance Conference, Limassol, Cyprus.30 Jun-02 Jul 2013.

Choudhry, T. \& Hassan, S. S. (2015). Exchange rate volatility and UK imports from developing countries: The effect of the global financial crisis. Journal of International Financial Markets, Institutions and Money, 39, 89-101.

Eichengreen, B.\&Gupta, P. (2013) The real exchange rate and export growth: are services different?World Bank

Frenkel, R. \&Rapetti, M. (2014). The real exchange rate as a target of macroeconomic policy MPRA Paper No. 59335

Genc, E. G. \&Artar, O. K. (2014). The effect of exchange rates on exports and imports of emerging countries. European Scientific Journal, 10(13), 128-141.

Guzman, M. Jose Antonio Ocampo,\&Joseph E. Stiglitz.(2018). Real exchange rate policies for economic development Journal of World Development (110), 51-62.

Hussain, S B., Hussain, S. \&Hussain, F. (2015). Exchange Rate Volatility During Different Exchange Rate Regimes and its Relationship with Exports of Pakistan. The Journal of Governance and Public Policy, ISSN: 2219-0562, Vol. VII, Issue. II

Hou, X. (2014). The RMB Exchange Rate Fluctuations Impact on the Export of LaborIntensive Industry Research. International Journal of Business and Social Science, 5(7)

Jiang, W. (2014). The effect of RMB exchange rate volatility on import and export trade in China International Journal of Academic Research in Business and Social Sciences, 4(1), 615.

Latief, R. \&Lefen, L. (2018). The effect of exchange rate volatility on international trade and foreign direct investment (FDI) in developing countries along one belt and one road International Journal of Financial Studies, 6(4), 86.

Leigh, M. D., Lian, W., Poplawski-Ribeiro, M., Szymanski, R., Tsyrennikov, V. \& Yang, H. (2017). Exchange rates and trade: A disconnect? International Monetary Fund

Kemal, M. A. (2005). Exchange rate instability and trade: The case of Pakistan (No. 186). Pakistan Institute of Development Economics, Islamabad, Pakistan. 
Khan, A. J., Azim, P. \& Syed, S. H. (2014). The impact of exchange rate volatility on trade: A panel study on Pakistan's trading partners. The Lahore Journal of Economics, 19(1), 31

Khattak, N. U. R., Tariq, M. \& Khan, J. (2012). Factors affecting the nominal exchange rate of Pakistan: An econometric investigation (1982-2008). Asian Economic and Financial Review, 2(2), 421

Korinek, A. (2011). Systemic risk-taking: amplification effects, externalities, and regulatory responses. ECB Working Paper No 1345.

Kumar, R., \&Dhawan, R. (1991). Exchange rate volatility and Pakistan's exports to the developed world, 1974-85 World development, 19(9), 1225-1240

Kurihara, Y. (2013). Effects of exchange rate fluctuations and financial development on international trade: Recent experience. International Journal of Business, Management and Economics Research, 4(5), 793-801

Marquez, J., \& Schindler, J. W. (2006). Exchange-Rate Effects on China's Trade: An Interim Report. FRB International Finance Discussion Paper, (861)

Nicita, A. (2013). Exchange Rates, International Trade and Trade Policies Policy Issues in International trade and Commodities Study Series No, 56, UNCTAD, New York and Geneva

Pesaran, M. H. \& Shin, Y. (1999). An Autoregressive Distributed Lag Modelling Approach to Cointegration Analysis. In Econometrics and Economic Theory in the 20th Century The Ragnar Frisch Centennial Symposium, Edited by Steiner Strom, Cambridge: Cambridge University Press

Pesaran, M. H., Shin, Y. \& Richard, J. S. (2001). Bounds Testing Approaches to the Analysis of Level Relationships. Journal of Applied Econometrics 16: 289-326

Razi, A., Shafiq, A., Ali, S. A. \& Khan, H. (2012).Determinants of exchange rate and its impact on Pakistani economy. Global Journal of Management and Business Research, 12(16)

Serenis, D. \&Serenis, P. (2010). Exchange rate volatility, the EU and sectoral exports: New empirical evidence from the chemical sector (1973-2005) Research in World Economy, 1(1), 47

Serenis, D. \&Tsounis, N. (2014). Exchange rate volatility and aggregate exports: evidence from two small countries ISRN Economics

Shahbaz, M., Jalil, A. \& Islam, F. (2010). Real exchange rate changes and trade balance in Pakistan: A revisit MPRA-Paper 27631. 
Šimáková, J. (2014). The impact of exchange rate development on Czech trade flows. Procedia Economics and Finance, 15, 129-136.

Šimáková, J. (2014). Relationship between the Poland's Trade Flows at the Commodity Level and the Zloty Exchange Rate In 8th International Scientific Conference Business and Management 2014 (pp. 305-312)

Shin, Y., Yu, B. \& Greenwood-Nimmo, M. (2014). Modeling asymmetric cointegration and dynamic multipliers in a nonlinear ARDL framework In Festschrift in Honor of Peter Schmidt (pp. 281-314) Springer, New York, NY

Li, X. Chang, H. L., Su, C. W. \& Dai, Y. (2017). Does Foreign Direct Investment Promote Exports in China? China Finance Review International

Tenreyro, S. (2007). On the trade impact of nominal exchange rate volatility Journal of Development Economics, 82(2), 485-508

Yarmukhamedov, S. (2007). Trade effects of exchange rate fluctuations: Evidence from Sweden.Social and Behavioral Science, Borlänge, p. 37 